\title{
Colonization of artificial seagrass versus time and distance from source*
}

\author{
Robert W. Virnstein** \& Mary Carla Curran*** \\ Harbor Branch Foundation, Inc., RR 1, Box 196, Fort Pierce, Florida 33450, USA
}

\begin{abstract}
Are seagrass-associated communities static? In order to measure the ability of seagrassassociated macrofauna to colonize 'empty' habitat patches, we studied the colonization of artificial seagrass, a natural seagrass mimic. In 2 separate experiments, we measured colonization (1) over a time series of 0.5 to $16 \mathrm{~d}$ and (2) over a distance series of 0 to $15 \mathrm{~m}$ from the source pool of colonists in a seagrass meadow in the Indian River lagoon, Florida. Colonization over time was rapid. Abundance and species richness peaked in 4 to $8 \mathrm{~d}$, while abundances of individual species continued to fluctuate. Colonization was rapid at all distances from the seagrass bed. Although gastropod abundance decreased with increasing distance, abundance of crustaceans increased with distance. At the margin of the seagrass bed, gastropods and crustaceans colonized in approximately equal abundance, whereas $15 \mathrm{~m}$ from the bed, crustaceans colonized 6 to 8 times as abundantly as gastropods. Relative to natural densities, the dominant crustacean Cymadusa compta (Amphipoda) colonized 38 times as abundantly as the dominant gastropod, Bittium varium. We attribute this increased crustacean colonization far from grassbeds to the 'nearest refuge' hypothesis, but also suggest an alternative predation hypothesis. Thus, seagrass-associated communities are not static. The short time scale of these experimental colonizations implies that the maintenance of strong correlations between plant and animal abundances in seagrass meadows requires strong pressures to counterbalance such rapid immigration (e.g. intense predation and/or habitat selection).
\end{abstract}

\section{INTRODUCTION}

Are benthic communities static? In seagrass meadows, if individuals are removed from a localized patch of seagrass, how rapidly do other individuals colonize such defaunated patches?

Concepts of the structure of the marine benthic communities are usually based on the implicit assumption that benthic animals are relatively stationary over time scales ranging from weeks to years. Recent evidence, however, has demonstrated instead that some epifauna are quite motile, can colonize habitats rapidly (Gunnill 1982, Bell \& Devlin 1983, Bell 1985, Leber 1985), and have high turnover rates (Howard 1985).

In seagrass meadows, many of the macrobenthic

- Harbor Branch Foundation Contribution No. 492

- Present address: Seagrass Ecosystems Analysts, 805 E. 46th Place, Vero Beach, Florida 32963, USA

-.. Present address: Department of Zoology, Victoria University of Wellington, Private Bag, Wellington, New Zealand

(c) Inter-Research/Printed in F. R. Germany animals associated with seagrass blades are motile crustaceans and gastropods. They generally move up and down seagrass blades while feeding on associated plants, animals, and organic matter, and serve as a major energy link to higher trophic levels in seagrass ecosystems (Young \& Young 1978, Nelson 1979a, 1981, Stoner 1980a, Livingston 1982, Virnstein et al. 1983, Leber 1985).

In order to measure the degree to which macrobenthic animals can find and colonize 'empty' habitat patches, we studied colonization of artificial seagrass (ASG) clumps. Artificial seagrass mimicked natural seagrass and was colonized by a similar suite of species (Moulton 1971, Macan \& Kitching 1972, Soszka 1975, Barber et al. 1979, Fitzhardinge 1983, Bell et al. 1985). We here compare the colonization of several types of substrata and examine the colonization sequence over time and the effect of distance from source of colonists. Our results demonstrate that seagrassassociated epifauna extensively colonize habitat patch islands (ASG clumps) within days at distances of at least $15 \mathrm{~m}$ from any seagrass. 


\section{STUDY AREA AND METHODS}

The Indian River is a shallow lagoon $(1.5 \mathrm{~m}$ mean depth) extending $182 \mathrm{~km}$ along the east coast of Florida, USA (Fig. 1), with extensive seagrass meadows in some shallow areas. At the Link Port study site, $79 \%$ of

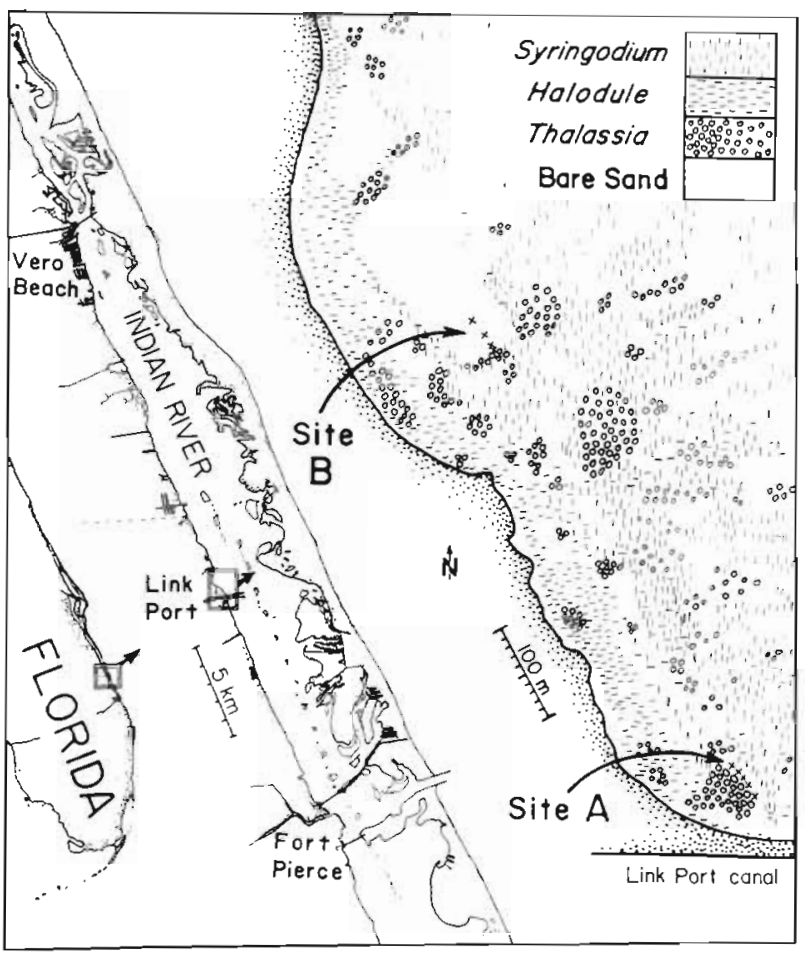

Fig. 1. Location of study sites in relation to seagrasses in the Indian River lagoon, Florida. Approximate placement of artificial seagrass clumps is indicated by small crosses

a 15 ha mapped area is covered by seagrasses, comprised of Syringodium filiforme $(47 \%)$, Halodule wrightii $(24 \%)$, and Thalassia testudinum ( $8 \%$ ) (Virnstein \& Carbonara 1985).

We performed 2 separate experiments at 2 different sites. The colonization rate experiment was conducted $40 \mathrm{~m}$ north of a peninsula adjacent to the Harbor Branch Foundation laboratories $\left(27^{\circ} 32.1^{\prime} \mathrm{N}, 80^{\circ} 20.9^{\prime} \mathrm{W}_{i}\right.$ Fig. 1 , Site A). ASG clumps were set out on a narrow sand patch near the border of a Thalassia testudinum bed, with Syringodium filiforme and Halodule wrightii nearby. Water depth was $0.5 \mathrm{~m}$. The colonization versus distance experiment was conducted $500 \mathrm{~m}$ further north, where a large bare-sand area is adjacent to an extensive seagrass meadow (water depth $=1.0 \mathrm{~m}$; Fig. 1, Site B). This sand/seagrass interface was relatively straight, distinct, and perpendicular to tidal currents (typically $<8 \mathrm{~cm} \mathrm{~s}^{-1}$ ). During this study, water temperature ranged from 26 to $31^{\circ} \mathrm{C}$, and salinity ranged from 25 to $30 \%$.

We used clumps of artificial seagrass (ASG) as con-

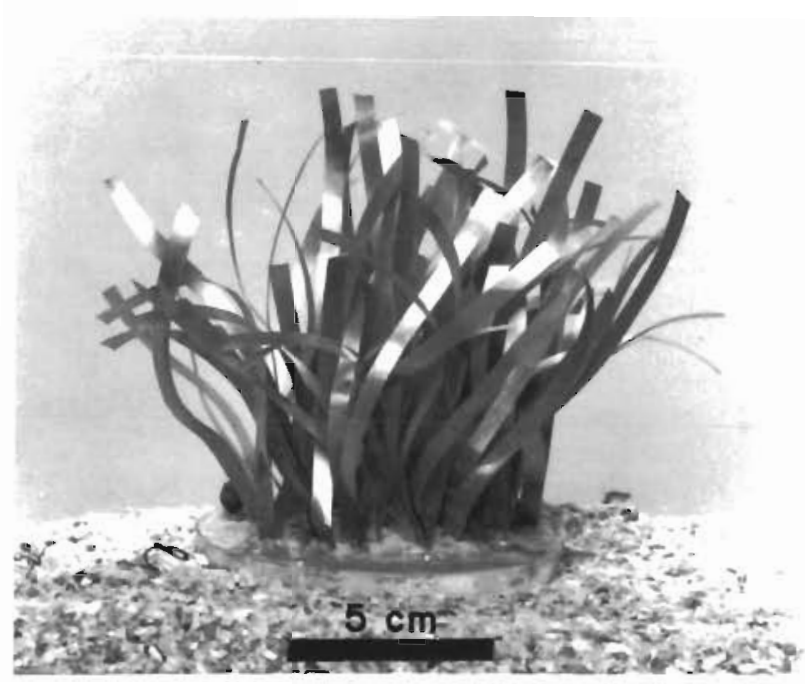

Fig. 2. A clump of artificial seagrass, containing $1000 \mathrm{~cm}^{2}$ of blade surface area, used in the colonization experiments

venient habitat-patch islands. ASG clumps (Fig. 2) were constructed of olefern, a green, polypropylene ribbon (Avisun Corporation, Milwaukee, Wisconsin) $5 \mathrm{~mm}$ wide, the same width as Thalassia testudinum blades. Each clump contained $1000 \mathrm{~cm}^{2}$ of blade surface area, comprised of 100 'blades' grouped into 25 'shoots' : 35 blades $8 \mathrm{~cm}$ long, 30 blades $10 \mathrm{~cm}$ long and 35 blades $12 \mathrm{~cm}$ long. Each shoot consisted of 1 blade of each length plus a fourth blade randomly selected from the remaining blade lengths. We anchored shoots in a thin layer of cement in $9.5 \mathrm{~cm}$ diameter, plastic Petri-dish lids and usually poured a thin layer of epoxy resin on top of the cement to secure the blades.

Deployment and recovery of clumps was rapid and simple. Clumps were set out on the sediment surface and later retrieved by gently lifting them a few centimeters off the sediment surface and then quickly scooping them up to the water's surface with a $30 \mathrm{~cm}$ diameter $0.5 \mathrm{~mm}$ mesh sieve. We put each clump and contents of the sieve in separate containers and returned them to the laboratory. There, we washed animals from clumps with a stream of tapwater (with nearly $100 \%$ efficiency, based on subsequent inspection of a few clumps) onto a $0.5 \mathrm{~mm}$ mesh sieve and transferred all retained material to $70 \%$ ethanol. Animals were then sorted, counted, and identified.

Comparison of substrata. For comparison with the epifauna of these 'standard' ASG samples, collections of 3 additional substrata were made at Site A (Fig. 1): narrow-bladed ASG clumps, natural Thalassia testudinum, and defaunated clumps of macroalgae. All were collected on 22 July, 1982. The 2 types of ASG clumps ( $\mathrm{n}=5$ of each) were set out for a colonization period of $1 \mathrm{~d}$. Clumps of both the standard (blades $5 \mathrm{~mm}$ wide) and the narrow-bladed ASG (blades 
$1.25 \mathrm{~mm}$ wide) had the same total surface area. The only difference was that narrow-bladed ASG clumps had blades slit lengthwise into 4 narrow blades. Thus we had ASG clumps similar in morphology to $T$. testudinum ('standard' ASG) and Halodule wrightii ('narrow' ASG).

Quantitative collections ( $\mathrm{n}=5$ ) of natural seagrassassociated fauna were made in the adjacent Thalassia testudinum bed using an epifauna sampler designed to sample only seagrass blades and associated fauna (Virnstein \& Howard unpubl.). Samples were placed in $10 \%$ formalin, returned to the laboratory, and washed on a $0.5 \mathrm{~mm}$ mesh sieve with a strong stream of tapwater to remove associated motile macrofauna, which were then stored in $70 \%$ ethanol prior to sorting, counting and identifying. Seagrass blades were dried at $60^{\circ} \mathrm{C}$ and weighed. Surface area of grassblades in each replicate was calculated from blade biomass using the surface area:biomass ratio of $515 \mathrm{~cm}^{2}$ (g dry $w t)^{-1}$ from Stoner (1980b). Abundances of macrofauna were then standardized to numbers of individuals per plant surface area (ind $1000 \mathrm{~cm}^{-2}$ ). Because T. testudinum samples had larger plant surface areas than ASG samples, numbers of species on $T$. testudinum were rarefied (Heck et al. 1975) based on the mean number of individuals expected in a $T$. testudinum sample of $1000 \mathrm{~cm}^{2}$ surface area (the same surface area as an ASG clump).

Colonization of drift algae, primarily Gracilaria spp., which are at times very abundant in the study area (Virnstein \& Carbonara 1985), was also compared to that of ASG. Individual plants of a red alga (Gracilaria tikvahiae) grown in culture were defaunated by dipping in freshwater and shaking vigorously (>95\% removal efficiency), trimmed to uniform weight with a surface area equivalent to that of an ASG clump (based on a surface area:biomass ratio of $272 \mathrm{~cm}^{2}$ (g dry $\left.w t\right)^{-1}$; Stoner 1980b) and placed in the field for colonization. These clumps ( $n=5$ ) were held in place on the sediment surface by small wire wickets. After $1 \mathrm{~d}$, they were collected in the same manner as ASG clumps and transferred to formalin. In the laboratory, these clumps were processed in the same manner as the Thalassia testudinum samples.

Rate of colonization. In the colonization rate experiment, 30 ASG clumps were set out and recovered during the period 6 to 22 July 1982 at Site A (see Fig. 1). We set out clumps on bare sand, $0.5 \mathrm{~m}$ from the edge of the grass bed and $0.5 \mathrm{~m}$ from each other. Collection time intervals were $0.5,1,2,4,8$, and $16 \mathrm{~d}$. For each time interval, we collected 5 replicates from randomly-assigned positions.

At each recovery time, we measured abundance of epiphytic algae on the ASG blades by scraping 6 blades (2 each of 8,10 , and $12 \mathrm{~cm}$ lengths) with forceps after gently rinsing them with distilled water to remove salts. Material removed was dried at $60^{\circ} \mathrm{C}$ and weighed.

Colonization versus distance from source pool. The second major experiment was designed to examine any differences in colonization with increasing distance from the source pool of colonists (i.e. from the adjacent seagrass meadows). In the extensive adjacent sand patch, we set out clumps of ASG various distances from the sand/seagrass border (Site B, Fig. 1), first for a $1 \mathrm{~d}$ time interval (22 to 23 Sep 1982) and then for a $4 \mathrm{~d}$ time interval (24 to $28 \mathrm{Sep} 1982$ ). For each time period, deployment distances were $0,0.5,1.5,5.0$, and $15.0 \mathrm{~m}$ from the margin of the seagrass bed. At each distance, clumps $(n=4)$ were placed $0.5 \mathrm{~m}$ apart in a line parallel to the sand/seagrass border, 2 on either side of a reference stake. Recovery and processing of samples were the same as that in the time series study.

To determine whether colonizing animals came from seagrass beds or were residing in unvegetated sediments near ASG clumps, four $8 \mathrm{~cm}$ diameter cores $5 \mathrm{~cm}$ deep and four $0.1 \mathrm{~m}^{2}$ scoops of the top $1 \mathrm{~cm}$ of sediment were taken in the area $15 \mathrm{~m}$ away from the seagrass at each of 3 times: $1000 \mathrm{~h}, 2100 \mathrm{~h}$ and $0200 \mathrm{~h}$. Samples were washed on a $0.5 \mathrm{~mm}$ mesh sieve and processed as described above.

Data analysis. For all analyses, we considered only the motile macroepifauna. We excluded strictly sessile species (e.g. barnacles and bryozoans), infauna (e.g. bivalves and deposit-feeding polychaetes), and those taxa normally considered to be meiofauna, which were not adequately retained by our $0.5 \mathrm{~mm}$ mesh sieve (e.g. nematodes and harpacticoid copepods). All abundances were standardized to uniform plant surface area (individuals $1000 \mathrm{~cm}^{-2}$ ).

To compare community composition between various times of collection in the colonization rate experiment, 2 similarity indices were used. Sørensen's (1948) Quotient of Similarity (QS) is a qualitative, presence/ absence index which compares species composition, measured as mean percent of species common to 2 collections. The second index, rho (van Belle \& Ahmad 1974), is a quantitative index which compares relative abundances of co-occurring species and measures the similarity of species dominance between 2 collections. For these similarity analyses, totals of the replicates from each collection (treatment) were used, with species represented by a single individual eliminated.

To compare epifaunal abundances in the various treatments (times or distances), 1-way analyses of variance (ANOVAs) were used. Where significant differences were indicated by the ANOVAs $(\alpha=0.05)$, individual means were compared using the a posteriori Student-Newman-Keuls multiple-range test (Sokal \& Rohlf 1969). 
Table 1. Comparison of motile fauna colonizing artificial seagrass clumps, narrow-bladed artificial seagrass clumps ('narrow ASG'), and Gracilaria tikvahiae macroalgae, all after $1 \mathrm{~d}$. The natural fauna of the adjacent Thalassia testudinum seagrass is compared to $16 \mathrm{~d}$ colonized artificial seagrass. Parameters compared are (A) qualitative similarity (QS) and quantitative (dominance) similarity (rho), (B) abundance, (C) number of species, and (D) numerically dominant species (species above the line together comprised $\geq 90 \%$ of total individuals)

\begin{tabular}{|c|c|c|c|c|c|c|c|}
\hline & & & \multicolumn{3}{|c|}{ Colonized over a $1 \mathrm{~d}$ period } & \multirow{2}{*}{$\begin{array}{l}16 \mathrm{~d} \\
\text { artificial } \\
\text { seagrass }\end{array}$} & \multirow{2}{*}{$\begin{array}{l}\text { Natural } \\
\text { Thalassia } \\
\text { testudinum }\end{array}$} \\
\hline & & & Narrow ASG & $\begin{array}{l}\text { Artificial } \\
\text { seagrass }\end{array}$ & $\begin{array}{l}\text { Gracilaria } \\
\text { tikvahiae }\end{array}$ & & \\
\hline \multicolumn{3}{|c|}{$\begin{array}{l}\text { A. Faunal similarity } \\
\text { QS } \\
\text { rho }\end{array}$} & $\begin{array}{l}0.800 \\
0.964\end{array}$ & $\begin{array}{l}0.95 \\
0.96\end{array}$ & & \multicolumn{2}{|l|}{$\begin{array}{l}0.786 \\
0.747\end{array}$} \\
\hline \multicolumn{3}{|c|}{$\begin{array}{l}\left.\text { B. Abundance (ind } 1000 \mathrm{~cm}^{-2}\right) \\
(\overline{\mathrm{x}} \pm \mathrm{SE})\end{array}$} & $75.4 \pm 22.6$ & $63.2 \pm 8.3$ & $180.8 \pm 14.9$ & $216.8 \pm 19.6$ & $163.4 \pm 15.9$ \\
\hline \multicolumn{3}{|c|}{$\begin{array}{l}\text { C. Number of species } \\
(\bar{x} \pm S E)\end{array}$} & $8.6 \pm 0.7$ & $11.0 \pm 1.3$ & $17.5 \pm 1.6$ & $19.6 \pm 2.0$ & $14.8 \pm 1.1$ \\
\hline \multirow{10}{*}{\multicolumn{2}{|c|}{ D. Dominant species: }} & 1 & Bittium varium & Bittium varium & Bittium varium & Bittium varium & Bittium varium \\
\hline & & 2. & $\begin{array}{l}\text { Cymadusa } \\
\text { compta }\end{array}$ & $\begin{array}{l}\text { Cymadusa } \\
\text { compta }\end{array}$ & $\begin{array}{l}\text { Cymodoce } \\
\text { faxoni }\end{array}$ & $\begin{array}{l}\text { Hargeria } \\
\text { rapax }\end{array}$ & $\begin{array}{l}\text { Cerithium } \\
\text { muscarum }\end{array}$ \\
\hline & & 3. & $\begin{array}{l}\text { Hippolyte } \\
\quad \text { pleuracanthus }\end{array}$ & $\begin{array}{l}\text { Hippolyte } \\
\text { pleuracanthus }\end{array}$ & $\begin{array}{l}\text { Cymadusa } \\
\text { compta }\end{array}$ & $\begin{array}{l}\text { Cymadusa } \\
\text { compta }\end{array}$ & $\begin{array}{l}\text { Modulus } \\
\text { modulus }\end{array}$ \\
\hline & & 4. & $\begin{array}{l}\text { Caecum } \\
\text { pulchellum } \\
\end{array}$ & $\begin{array}{l}\text { Cymodoce } \\
\text { faxoni }\end{array}$ & Nemerteans & $\begin{array}{l}\text { Caecum } \\
\text { pulchellum }\end{array}$ & $\begin{array}{l}\text { Crepidula } \\
\text { convexa }\end{array}$ \\
\hline & & 5. & Nassarius vibex & Nassarius vibex & Modulus modulus & Crepidula convexa & Ercolania fuscata \\
\hline & & 6. & $\begin{array}{l}\text { Hargeria } \\
\quad \text { rapax }\end{array}$ & $\begin{array}{l}\text { Erichsonella } \\
\text { attenuata }\end{array}$ & $\begin{array}{l}\text { Hippolyte } \\
\text { pleuracanthus }\end{array}$ & $\begin{array}{l}\text { 'Odostomia' } \\
\text { engonia }\end{array}$ & $\begin{array}{l}\text { Polydora } \\
\text { ligni }\end{array}$ \\
\hline & & 7. & $\begin{array}{l}\text { Odostomia' } \\
\text { engonia }\end{array}$ & $\begin{array}{l}\text { Modulus } \\
\text { modulus } \\
\end{array}$ & $\begin{array}{l}\text { Phascolion } \\
\text { cryptus }\end{array}$ & $\begin{array}{l}\text { Astyris } \\
\text { lunata }\end{array}$ & Nemerteans \\
\hline & & 8. & $\begin{array}{l}\text { Cymodoce } \\
\text { faxoni }\end{array}$ & $\begin{array}{l}\text { Hargeria } \\
\text { rapax }\end{array}$ & $\begin{array}{l}\text { Caecum } \\
\text { pulchellum }\end{array}$ & Polydora ligni & Hargeria rapax \\
\hline & & 9. & $\begin{array}{l}\text { Crepidula } \\
\text { plana }\end{array}$ & $\begin{array}{l}\text { Cerithium } \\
\text { muscarum }\end{array}$ & $\begin{array}{l}\text { Cerithium } \\
\text { muscarum }\end{array}$ & $\begin{array}{l}\text { Phascolion } \\
\text { cryptus }\end{array}$ & $\begin{array}{l}\text { Typosyllis } \\
\text { alternata } \\
\end{array}$ \\
\hline & & 10. & $\begin{array}{l}\text { Cerithium } \\
\text { muscarum }\end{array}$ & Nemerteans & $\begin{array}{l}\text { Nassarius } \\
\text { vibex }\end{array}$ & $\begin{array}{l}\text { Modulus } \\
\text { modulus }\end{array}$ & $\begin{array}{l}\text { Cymadusa } \\
\text { compta }\end{array}$ \\
\hline
\end{tabular}

\section{RESULTS}

\section{Comparison of substrata}

Highly similar suites of species were found on all substrata, both natural and artificial. Faunal differences were mainly ones of relative abundance, e.g. greater dominance of gastropods (the top 5 species) on Thalassia testudinum (Table 1). Therefore, the fauna that colonized ASG clumps provided a reasonable representation of the fauna on natural macrophytes.

In comparisons of faunas in the three $1 \mathrm{~d}$ colonization collections, the standard-width ASG was highly similar to both narrow ASG and Gracilaria tikvahiae, with 80 and $96 \%$, respectively, of species in common and $96 \%$ dominance similarity (Table 1 ). In all 3 collections, the top 10 numerically dominant species included: the gastropod Bittium varium, the amphipod Cymadusa compta, the shrimp Hippolyte pleuracanthus, the isopod Cymodoce faxoni, and the gastropods Cerithium muscarum and Nassarius vibex (Table 1). $H$. pleuracanthus were rare in the later, Day 16 and natural Thalassia testudinum collections.
The fauna of colonized Day 16 ASG clumps and natural Thalassia testudinum had $79 \%$ of their species in common and $75 \%$ dominance similarity (Table 1 ). Again, Bittium varium was dominant in both collections.

\section{Rate of colonization}

Colonization of ASG clumps was rapid. Over the first $4 \mathrm{~d}$, abundance and species richness increased linearly, at rates of 62 ind $d^{-1}$ and 6 species $d^{-1}$. Both number of individuals and number of species reached maximum values and leveled off in 4 to $8 \mathrm{~d}$ (Fig. 3A).

Abundances of individual species, however, fluctuated more widely. For example, the 2 most abundant species (Bittium varium and Cymadusa compta) reached maximum abundance after 4 to $8 \mathrm{~d}$ and then declined significantly (Fig. 3B, Table 2); in contrast, the next 3 most abundant species (Hargeria rapax, Caecum pulchellum, and Crepidula convexa) continued to increase in abundance (Fig. $3 \mathrm{C}$, Table 2).

One measure of community development is the rate of change in community structure. Both species com- 

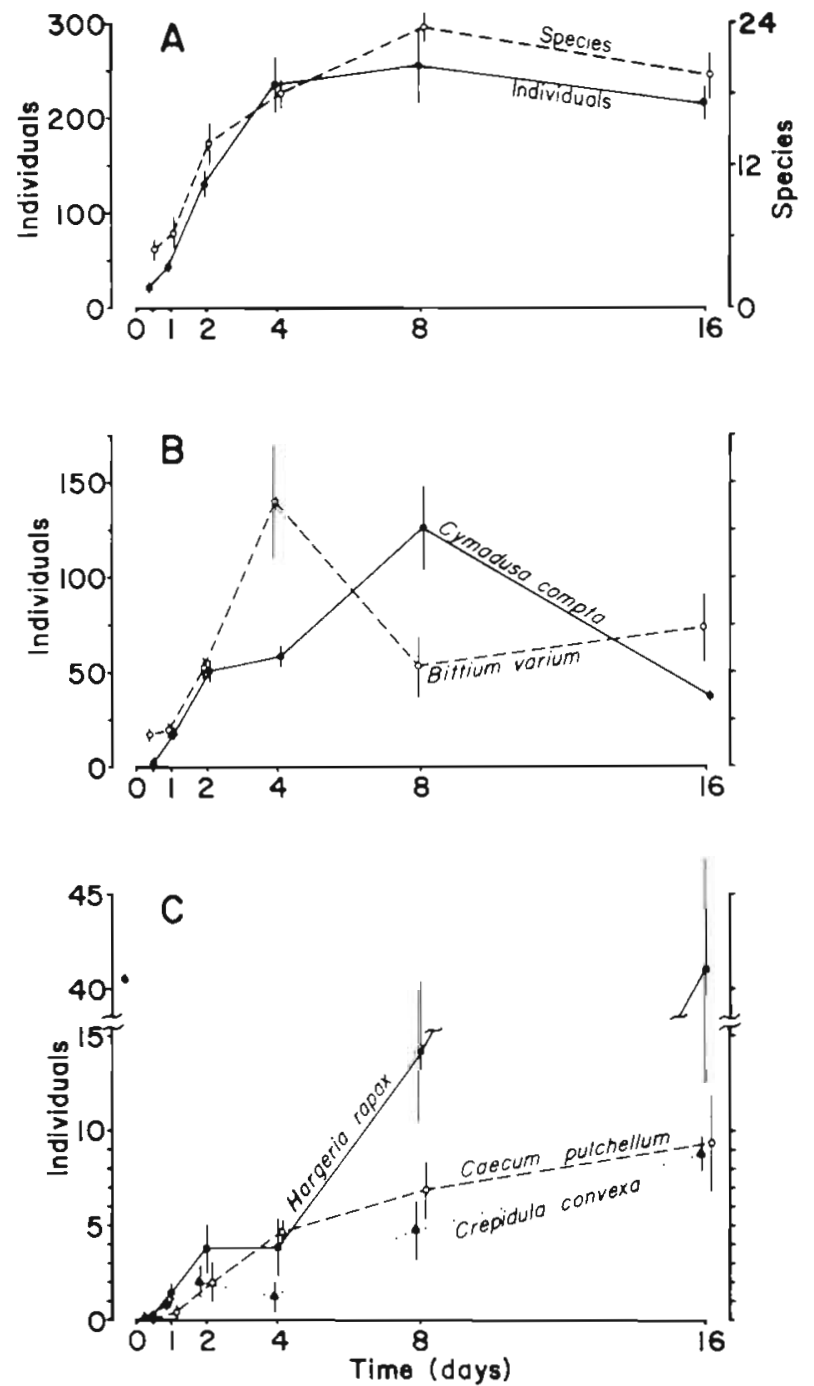

Fig. 3. Abundance of motile epifauna colonizing artificial seagrass clumps, versus time. Means $\pm \mathrm{SE}$. (A) Total individuals and numbers of species. (B) The 2 numerically dominant species, Cymadusa compta (amphipod) and Bittium varium (gastropod). (C) The next 3 most abundant species, Hargeria rapax (tanaid) and Caecum pulchellum and Crepidula convexa (gastropods)

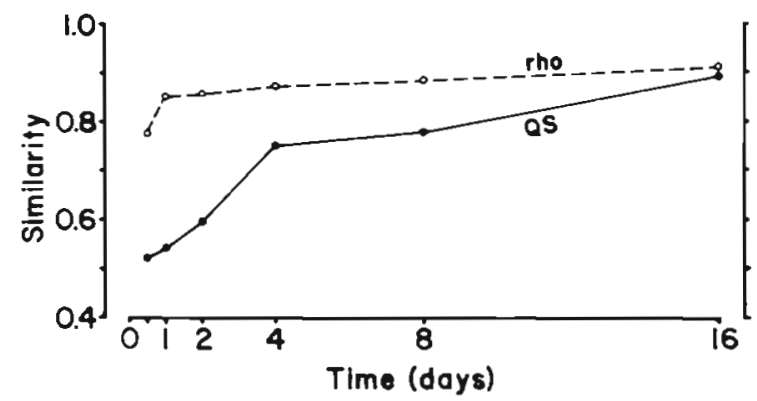

Fig. 4. Qualitative (QS) and quantitative, dominance (rho) similarity of each epifaunal collection to the final, Day 16 collection. Similarity at Day 16 is the mean similarity between all replicate artificial seagrass clumps
Table 2. Significant differences between abundances on artificial seagrass after various times of colonization. Any 2 times joined by the same underline indicate nonsignificant differences $(\mathrm{P}>0.05)$ between means, based on a posteriori Student-Newman-Keuls test. Overall F-value from each ANOVA is given. Means are ordered from minimum (left) to maximum (right)

\begin{tabular}{|c|c|c|c|c|c|c|c|}
\hline \multirow{2}{*}{$\frac{\text { Parameter }}{\text { No. individuals }}$} & \multicolumn{6}{|c|}{ Number of days } & \multirow{2}{*}{$\frac{\text { F-value }}{19.86}$} \\
\hline & 0.5 & 1 & 2 & 16 & 4 & 8 & \\
\hline No. species & $\underline{0.5}$ & 1 & $\underline{2}$ & $\underline{4}$ & $\underline{16}$ & 8 & 25.73 \\
\hline Crustaceans & $\underline{0.5}$ & 1 & $\underline{2}$ & 4 & 16 & 8 & 19.59 \\
\hline Gastropods & $\underline{0.5}$ & 1 & 2 & 8 & $\underline{16}$ & 4 & 10.44 \\
\hline Bittium varium & $\underline{0.5}$ & 1 & 8 & 2 & 16 & 4 & 7.76 \\
\hline Cymadusa compta & $\underline{0.5}$ & 1 & 16 & 2 & 4 & 8 & 19.12 \\
\hline Hargeria rapax & 0.5 & 1 & 2 & $\underline{4}$ & 8 & 16 & 27.20 \\
\hline Caecum pulchellum & 0.5 & 1 & 2 & 4 & 8 & 16 & 8.24 \\
\hline Crepidula convexa & $\underline{0.5}$ & 1 & 4 & 2 & 8 & 16 & 12.91 \\
\hline Epiphyte weight & $\underline{0.5}$ & 1 & 2 & 4 & 8 & 16 & 32.58 \\
\hline
\end{tabular}

position (as measured by the quotient of similarity, QS) and relative dominance (as measured by rho) of the developing community rapidly and continually approached that of the final, Day 16 community (Fig. 4).

Although Bittium varium and Cymadusa compta colonized in roughly equal numbers (Fig. $3 \mathrm{~B}$ ), there were large differences between these 2 species relative to natural densities. $B$. varium colonized ASG in densities approximately equal to those naturally occurring in the adjacent seagrass bed. The ratio of $B$. varium density (per 'plant' surface area) on ASG clumps (mean of Days 4 to 16 ) to that on Thalassia testudinum was 1.2:1. In contrast, C. compta colonized ASG in densities far exceeding natural density; the colonized:natural density ratio was $46: 1$. Thus, compared to natural abundance, $C$. compta colonized ASG disproportionately faster than $\operatorname{did} B$, varium.

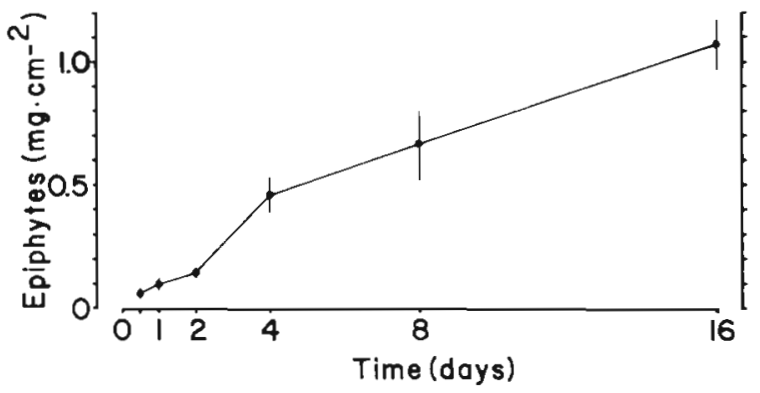

Fig. 5. Abundance of epiphytes per artificial seagrass blade surface area versus time. Means $\pm \mathrm{SE}$ 
Table 3. Abundance of animals colonizing artificial seagrass (ASG) clumps compared with abundance in adjacent, unvegetated sediments. Values given are total number of individuals for the top 10 species on 8 ASG clumps $15 \mathrm{~m}$ from seagrass bed (Days 1 and 4 combined) and in 24 sediment samples (total area $=1.26 \mathrm{~m}^{2}$ ) from the surrounding unvegetated sand

\begin{tabular}{|lrr|}
\hline \multicolumn{1}{c}{ Species } & \multicolumn{2}{c|}{ No. individuals } \\
& ASG & Sand \\
\hline Cymadusa compta & 541 & 3 \\
Cymodoce faxoni & 201 & 1 \\
Gitanopsis laguna & 97 & 1 \\
Grandidierella bonnieroides & 61 & 1 \\
Bittium varium & 60 & 2 \\
Gobiosoma robustum & 24 & 0 \\
Astyris lunata & 21 & 0 \\
Caecum pulchellum & 12 & 140 \\
Hippolyte pleuracanthus & 7 & 0 \\
Crepidula convexa & 7 & 1 \\
& & \\
\hline
\end{tabular}

Table 4. Significant differences between abundances on artificial seagrass after $4 \mathrm{~d}$ at various distances from the seagrass bed. Any 2 distances joined by the same underline indicate nonsignificant differences $(P>0.05)$ between means, based on a posteriori Student-Newman-Keuls test. Overall F-value from each ANOVA is given. Means are ordered from minimum (left) to maximum (right)

\begin{tabular}{|c|c|c|c|c|c|}
\hline Parameter & & $\begin{array}{l}\text { Dist } \\
\text { gras }\end{array}$ & $\begin{array}{l}\text { ance from } \\
\text { ss bed }(\mathrm{m})\end{array}$ & & $\begin{array}{c}\text { F- } \\
\text { value }\end{array}$ \\
\hline No. individuals & $\underline{0}$ & 0.5 & 1.515 & 5 & 5.25 \\
\hline No. species & $\underline{0}$ & 0.5 & $15 \quad 1.5$ & 5 & 4.07 \\
\hline Crustaceans & $\underline{0}$ & 0.5 & 1.515 & 5 & 14.17 \\
\hline Gastropods & $\underline{15}$ & 5 & $1.5 \quad 0.5$ & 0 & 2.77 \\
\hline Cymadusa compta & $\underline{0}$ & 0.5 & 1.55 & 15 & 7.58 \\
\hline Cymadoce faxoni & $\underline{0}$ & 0.5 & 1.515 & $\underline{5}$ & 13.15 \\
\hline Gitanopsis laguna & $\underline{0.5}$ & 0 & $1.5 \quad 5$ & 15 & 4.24 \\
\hline $\begin{array}{l}\text { Grandidierella } \\
\text { bonnieroides }\end{array}$ & $\underline{0.5}$ & 0 & $1.5 \quad 5$ & 15 & 3.94 \\
\hline $\begin{array}{l}\text { Pagurus } \\
\text { maclaughlinae }\end{array}$ & $\underline{15}$ & 5 & $1.5 \quad 0.5$ & 0 & 3.24 \\
\hline Bittium varium & $\underline{15}$ & 5 & $1.5 \quad 0.5$ & 0 & 7.43 \\
\hline Crepidula convexa & $\underline{15}$ & 1.5 & $5 \quad 0.5$ & 0 & 1.14 \\
\hline Gobiosoma robustum & $\underline{0}$ & 0.5 & 1.55 & 15 & 4.78 \\
\hline
\end{tabular}

Related perhaps to the increasing abundance of certain species, was the increase in abundance of epiphytes on ASG blades (Fig. 5). Rate of epiphyte accu-
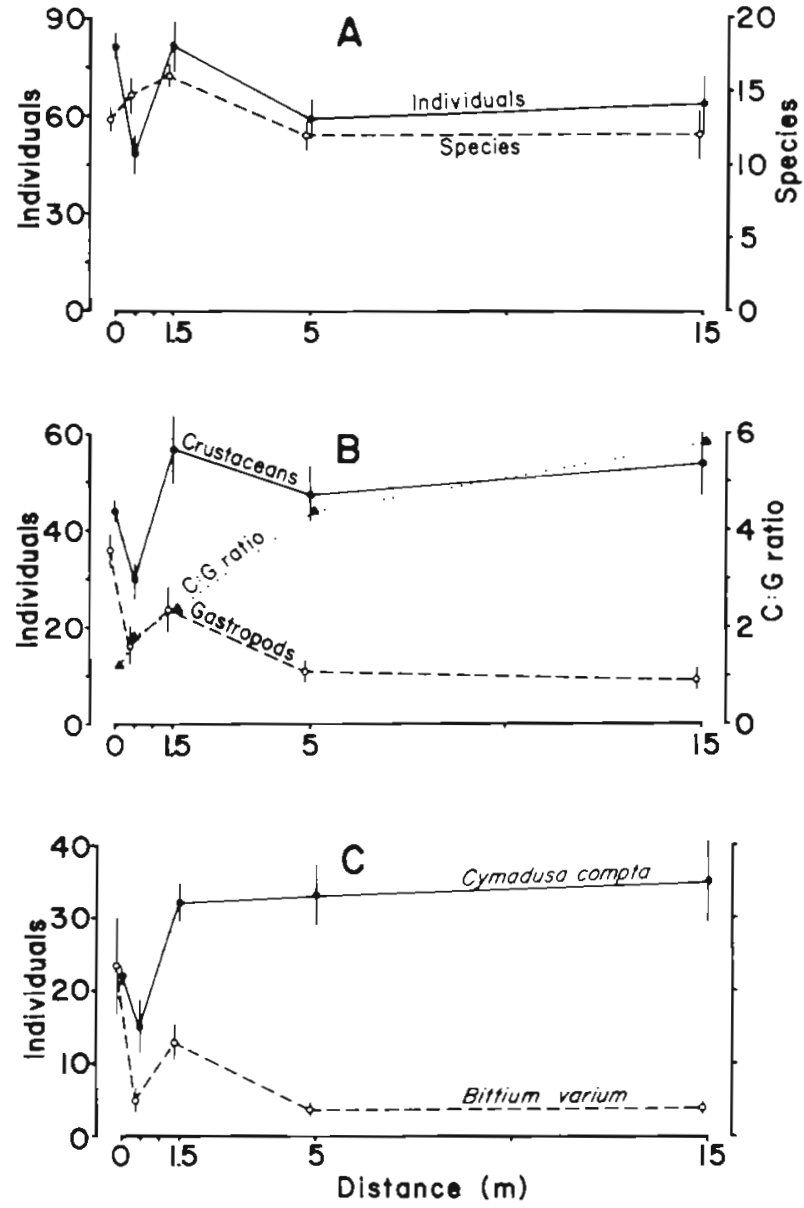

Fig. 6. Abundance of motile epifauna colonizing artificial seagrass after $1 \mathrm{~d}$, versus distance from seagrass. Means \pm SE. (A) Total individuals and number of species. (B) Total crustacean and gastropod individuals and their ratio. (C) The numerically dominant crustacean (Cymadusa compta) and gastropod (Bittium varium)

mulation was greater ( $\mathrm{P}<0.02$, $t$-test) during the first $4 \mathrm{~d}$ than during the next $12 \mathrm{~d}$.

\section{Source of colonists}

The source of colonists was primarily the surrounding seagrass beds, not the adjacent sediment. Densities of seagrass-associated animals were very low at the unvegetated sand site $15 \mathrm{~m}$ from seagrass beds (Table 3). Of the 10 most abundant species colonizing ASG, only the gastropod Caecum pulchellum was abundant in the sediment.

\section{Colonization versus distance}

Colonization of ASG clumps was rapid at all distances from the adjacent seagrass bed and at both 
times. After $1 \mathrm{~d}$, ASG clumps averaged 67 individuals and 14 species. After $4 \mathrm{~d}$, each clump had a mean of 157 individuals and 19 species.

After $1 d$, total numbers of individuals and number of species exhibited no consistent pattern with distance from the seagrass bed (Fig. 6A). Total abundance at $15 \mathrm{~m}$ (63.5 ind clump ${ }^{-1}$ ) was not significantly different than that at $0 \mathrm{~m}\left(81.2\right.$ ind clump $\left.{ }^{-1}\right)$. Gastropod abundance declined with increasing distance, while crustacean abundance was least near the seagrass bed (Fig. $6 \mathrm{~B})$. This combination of decreasing gastropod and increasing crustacean abundance resulted in a change in the ratio of abundance of crustaceans-to-gastropods (C: $G$ ratio) from $1.2: 1$ at the seagrass border to $5.8: 1$ at $15 \mathrm{~m}$. This pattern was primarily due to the top 2 dominant species, the amphipod Cymadusa compta and the gastropod Bittium varium. Abundances of these 2 species were the same at $0 \mathrm{~m}$, but at $15 \mathrm{~m}$, abundance of C. compta increased $59 \%$ and $B$. varium decreased $83 \%$ (Fig. 6C).

After $4 d$, patterns of abundance were more clearly established. Both numbers of individuals and numbers of species exhibited a trend of increasing with distance from the seagrass bed, with maxima at $5 \mathrm{~m}$ (Fig. 7A, Table 4). Crustacean abundance increased with dis- tance from vegetation (Fig. 7B), and was significantly greater at both 5 and $15 \mathrm{~m}$ than closer to the seagrass bed (Table 4). In contrast, gastropod abundance tended to decrease with increasing distance (Fig. 7B). This combination of increasing abundance of crustaceans and decreasing abundance of gastropods increased the crustacean:gastropod ratio from $1.4: 1$ at $0 \mathrm{~m}$ to $8.5: 1$ at $15 \mathrm{~m}$ (Fig. 7B). Most individual crustacean species also reflected this pattern of increasing abundance with distance from the grassbed. Cymadusa compta, Cymodoce faxoni, Gitanopsis laguna and Grandidierella bonnieroides were all significantly more abundant far from the seagrass bed than close to it (Fig. 7C, Table 4). The hermit crab Pagurus maclaughlinae (usually in Modulus modulus shells) responded more like the gastropods and was the only one of the top 9 species of crustaceans that decreased with increasing distance (Table 4).

Colonization patterns reflected motility abilities. Gastropods and hermit crabs, that crawl on the sediment surface, decreased in abundance with increasing distance (Fig. 7D). In contrast, the goby Gobiosoma robustum and crustaceans that can swim increased in abundance with increasing distance (Fig. 7C, Table 4).
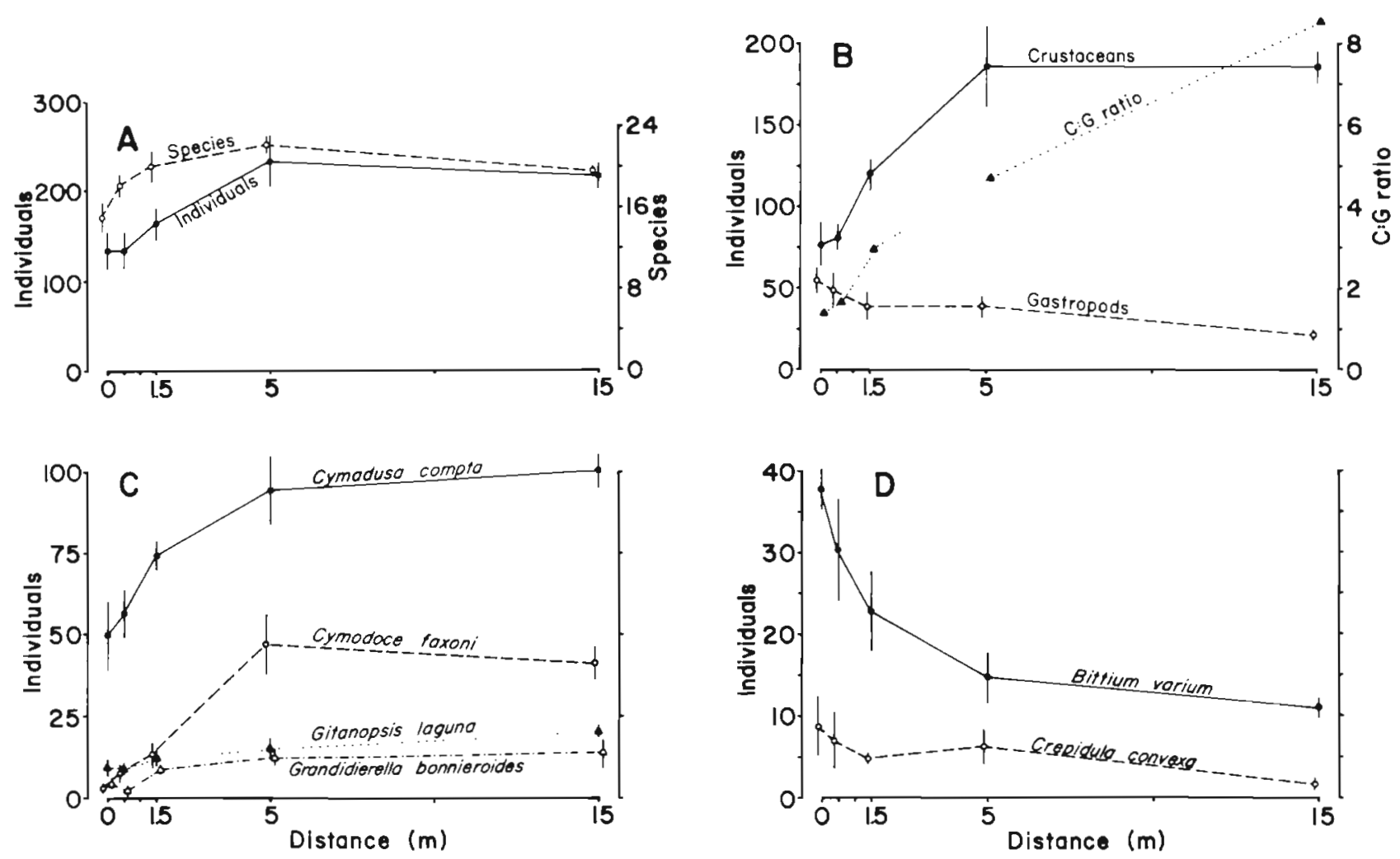

Fig. 7. Abundance of motile epifauna colonizing artificial seagrass after $4 \mathrm{~d}$, versus distance from seagrass. Means \pm SE. (A) Total individuals and number of species. (B) Total crustacean and gastropod individuals and their ratio. (C) The 4 most abundant crustaceans. (D) The 2 most abundant gastropods 


\section{DISCUSSION}

Seagrass communities are certainly not static. Artificial seagrass (ASG) clumps provided convenient, easily manipulated units for us to demonstrate that colonization by small seagrass-associated epifauna was extremely rapid. Although there were differences in relative abundance, the fauna that colonized ASG clumps was representative of that on natural seagrass and macroalgae. Other work with artificial seagrass by Moulton (1971), Macan \& Kitching (1972), Soszka (1975), Barber et al. (1979), Fitzhardinge (1983) and Bell et al. (1985) supports this conclusion.

Seagrass epiphytes not only provide the main source of food for most of the small motile epifauna studied here (Fry 1984, Kitting et al. 1984), but with heavy growth also increase habitat space and may increase refuge (M. O. Hall, pers. comm. 1984). Thus, one would expect a positive correlation between abundances of epiphytes and small epifauna. However, although abundance of epiphytes on ASG continually increased (Fig. 5), animal abundance and species richness did not continue to increase, but instead peaked within $8 \mathrm{~d}$ (Fig. 3A).

Initial colonization of ASG clumps was rapid, even though these clumps initially consisted of bare plastic blades; several species colonize within the first few hours (Virnstein, unpubl, data). Development of a bacterial and diatom film can be extremely rapid, however (Cuba \& Blake 1983), and may provide an initial food source for early colonists. Although epiphytes may provide both increased refuge and food for colonists, we hypothesize that initial colonization is in response to the presence of physical structure, not to the presence of food. Later, successional stages might be governed more strongly by competition for resources within clumps or by predation, either from within or outside clumps.

Because community development exhibits non-random patterns, we infer that seagrass-associated epifauna represent structured communities rather than non-interactive assemblages. When densities peak and then level off, is this due to competition for resources (either intra-or inter-specific), or due to control by predators (either later-colonizing, e.g. Nelson $1979 \mathrm{~b}$, or widely-foraging)? Are the initially high densities of some species simply due to microhabitat selectivity (e.g. Leber 1985)? Testing of these alternative hypotheses will help determine the forces that structure seagrass-associated communities.

Even as far away as $15 \mathrm{~m}$ from seagrass beds, colonization of ASG clumps was surprisingly rapid. The combination of decreasing gastropod abundance and increasing crustacean abundance with increasing distance demonstrates that over distances of several meters, crustaceans are clearly the more prolific colonizers. The more motile crustaceans can not only actively swim into the water column, but also might be passively carried by tidal currents. Presumably at some distance, crustacean colonization would decline. Gunnill (1982) found that colonization by a gammarid amphipod and a harpacticoid copepod decreased sharply with distance from source; neither crustacean colonized algal clumps $30 \mathrm{~m}$ away.

To account for this puzzling pattern of increasing crustacean abundance with increasing distance from seagrass beds (Fig. 7B), we suggest a 'nearest refuge' hypothesis. This assumes that, for whatever reasons, crustaceans leave seagrass beds and temporarily become dispersed over bare sand, where they are more vulnerable to predators (Robertson \& Howard 1978, Nelson 1979a, Coen et al. 1981, Heck \& Thoman 1981. Stoner 1982, Orth et al. 1984, Leber 1985) and then seek refuge. Those individuals close to seagrass beds find refuge either in ASG clumps or in the adjacent seagrass. Far from seagrass, however, the nearest available refuge was that provided by ASG clumps. Thus, ASG clumps far from seagrass beds would be colonized more rapidly because such clumps would provide nearest refuge for a potentially greater number of individuals. It is not known whether, or at what distance, individuals perceive and seek the refuge, or merely randomly bump into it.

An alternative hypothesis is that predation intensity is greater near seagrass beds, in which potential predators are more abundant (Virnstein et al. 1983, Summerson \& Peterson 1984), similar to the greater grazing pressure adjacent to coral reefs (Ogden et al. 1973). Actual abundance of the dominant predator collected in ASG clumps in this study, the goby Gobiosoma robustum, a known predator on amphipods (Kulczycki et al. 1981), was instead significantly more abundant in ASG clumps at $15 \mathrm{~m}$ than near the seagrass bed (Table 4). Foraging predators, however, such as pinfish and penaeid shrimp, were not sampled by this technique.

\section{Implications}

The ability to colonize habitats quickly and over distances of several meters questions the prevailing concept of a more static structure of seagrass-associated communities. Such rapid colonization suggests that any 'empty' habitat will be quickly colonized. If, for example, predators remove prey from a patch of seagrass, this defaunated patch could be recolonized within days. If differential abundance in seagrass patches is due to differences in predation intensity, as proposed by Stoner (1983), Lewis (1984) and Orth et al. (1984), how can these low-density patches be main- 
tained in the face of such rapid recolonization? Predation intensity must be severe enough and continuous enough to maintain such density differences. An alternative hypothesis is that animals preferentially select one habitat patch over the other.

Given such rapid colonization and high rate of turnover (Howard 1985), one might easily misinterpret some observed spatial differences. For example, if a sample from one seagrass site has twice as many animals as a second seagrass sample from a few meters away and of apparent equal structural complexity, such a difference has generally been attributed either to some unperceived heterogeneity in the physical habitat (e.g. differences in seagrass biomass) or to differences in initial settlement (recruitment) of individuals (e.g. Hayward 1980, Seed \& O'Connor 1981). Instead, we might interpret such a pattern as possibly (and temporarily) resulting either from recent habitat selection or from differential predation (e.g. Leber 1985); in a few days, the pattern could be reversed, with the second site having more individuals. In describing the structure of the motile epifauna associated with seagrass communities, one must be aware of this strong short-term temporal component, perhaps analogous to the 'contemporaneous disequilibrium' of plankton communities (Hutchinson 1961).

The effect of distance or size scale of a disturbance would vary between taxonomic groups. For example, a large-scale disturbance would likely have a greater and longer-lasting effect on gastropods than on more motile crustaceans.

Several questions about causes and consequences of such motility patterns remain unanswered. Seagrasses provide habitat, food, and refuge from predators for associated fauna. Why leave such a haven? Some possible advantages of leaving include: (1) temporarily escaping from predators, (2) avoiding competitors, (3) searching for food after depleting that locally available, and (4) finding mates (Robertson \& Howard 1978). What is the increase in predation vulnerability upon leaving a seagrass bed? Compared to dense seagrass, bare sand offers seagrass-associated epifauna little protection from predators (Nelson 1979a, Coen et al. 1981, Heck \& Thoman 1981, Stoner 1982, Main 1983, Orth et al. 1984, Leber 1985), and thus supports a different suite of species (Virnstein et al. 1983). How and from what distance do animals perceive ASG relative to natural seagrass? Many distributional patterns could possibly be explained by strong habitat preferences.

In summary, seagrass-associated motile epifauna quickly colonized patches of ASG within a few days and at distances of several meters. One major implication about the structure of seagrass-associated communities is that very strong pressures (e.g. intense predation and/or habitat selection) would be required to maintain patches of low density in the face of such rapid and extensive colonization.

Acknowledgements. Kalani Cairns, Paul Mikkelsen and Mary Ann Capone identified the specimens. Paul ran the data analyses, and Kalani drafted the figures. Paul, Kalani, Kevan Main and Ken Leber reviewed earlier drafts of the manuscript. Ken, Kevan, Rob Howard and Graham Lewis contributed many helpful discussions. Thorough anonymous reviews eliminated many inconsistencies.

\section{LITERATURE CITED}

Barber, W. E., Greenwood, J. G., Crocos, P. (1979). Artificial seagrass - a new technique for sampling the community. Hydrobiologia 65: 135-140

Bell, J. D., Steffe, A. S., Westoby, M. (1985). Artificial seagrass: How useful is it for field experiments on fish and macroinvertebrates. J. exp. mar. Biol. Ecol. 90: 171-177

Bell, S. S. (1985). Habitat complexity of polychaete tube-caps: Influence of architecture on dynamics of a meiobenthic assemblage. J. mar. Res. 43: 647-671

Bell, S. S., Devlin, D. J. (1983). Short-term macrofaunal recolonization of sediment and epibenthic habitats in Tampa Bay, Florida. Bull. mar Sci. 33: 102-108

Coen, L. D., Heck, K. L., Jr., Abele, L. G. (1981). Experiments on competition and predation among shrimps of seagrass meadows. Ecology 62: 1484-1493

Cuba, T. R., Blake, N. J. (1983). The initial development of a marine fouling assemblage on a natural substrate in a tropical estuary. Botanica mar. 26: 259-264

Fitzhardinge, R. (1983). Comparisons of the invertebrate faunas colonizing soft sediments in two different habitats. Bull, mar. Sci. 33: 745-752

Fry, B. (1984). ${ }^{13} \mathrm{C} /{ }^{12} \mathrm{C}$ ratios and the trophic importance of algae in Florida Syringodium filiforme seagrass meadows. Mar. Biol. 79: 11-19

Gunnill, F. C. (1982). Macroalgae as habitat patch islands for Scutellidium lamellipes (Copepoda: Harpacticoida) and Ampithoe tea (Amphipoda: Gammaridae). Mar. Biol. 69: 103-116

Hayward, P. J. (1980). Invertebrate epiphytes of coastal marine algae. In: Price, J. H., Irvine, D. E. G., Farnham, W. F. (ed.) The shore environment, Vol. 2, Ecosystems. Systematics Association Special Vol. No. 17(b). Academic Press, New York, p. 761-787

Heck, K. L. Jr., Thoman, T. A. (1981). Experiments on predator-prey interactions in vegetated aquatic habitats. J. exp. mar. Biol. Ecol. 53: 125-134

Heck, K. L. Jr., van Belle, G., Simberloff, D. S. (1975). Explicit calculation of the rarefaction diversity measurement and the determination of sufficient sample size. Ecology 56: $1159-1161$

Howard, R. K. (1985). Measurements of short-term turnover of epifauna within seagrass beds using an in situ staining method. Mar. Ecol. Prog. Ser. 22: 163-168

Hutchinson, G. E. (1961). The paradox of the plankton. Am. Nat. 95: 137-145

Kitting, C. L., Fry, B., Morgan, M. D. (1984). Detection of inconspicuous epiphytic algae supporting food webs in seagrass meadows. Oecologia (Berl.) 62: 145-149

Kulczycki, G. R., Virnstein, R. W., Nelson, W. G. (1981). The relationship between fish abundance and algal biomass in 
a seagrass-drift algae community. Estuar. coast. Shelf Sci. 12: $341-347$

Leber, K. M. (1985). The influence of predatory decapods, refuge and microhabitat selection on seagrass communities. Ecology 66: 1951-1964

Lewis, F. G. III. (1984). Distribution of macrobenthic crustaceans associated with Thalassia, Halodule and bare sand substrata. Mar. Ecol. Prog. Ser 19: 101-113

Livingston, R. J. (1982). Trophic organization of fishes in a coastal seagrass system. Mar. Ecol. Prog. Ser. 7: 1-12

Macan, T. T., Kitching, A. (1972). Some experiments with artificial substrata. Verh. int. Verein. Limnol. 18: 213-220

Main, K. L. (1983). Behavioral response of a caridean shrimp to a predatory fish. Ph. D. dissertation, Florida State University, Tallahassee

Moulton, M. P. (1971). An inquiry into the use of plastic 'grass' as a substitute for Thalassia. M. S. thesis, Florida State University, Tallahassee

Nelson, W. G. (1979a). Experimental studies of selective predation on amphipods: consequences for amphipod distribution and abundance. J. exp. mar. Biol. Ecol. 38: 225-245

Nelson, W. G. (1979b). An analysis of structural pattern in an eelgrass (Zostera marina L.) amphipod community. J. exp. mar. Biol. Ecol. 39: 213-264

Nelson, W. G. (1981). Experimental studies of decapod and fish predation on seagrass macrobenthos. Mar. Ecol. Prog. Ser. 5: 141-149

Ogden, J. C., Brown, R. A., Salesky, N. (1973). Grazing by the echinoid Diadema antillarum Philippi: formations of halos around West Indian patch reefs. Science 182: 715-717

Orth, R. J., Heck, K. L., Jr., van Montfrans, J. (1984). Seagrass faunal communities: a review of the influence of plant structure and prey life style on predator-prey relationships. Estuaries 7: 339-350

Robertson, A. I., Howard, R. K. (1978). Diel trophic interactions between vertically-migrating zooplankton and their fish predators in an eelgrass community. Mar. Biol. 48 : $207-213$
Seed, R., O'Connor, R. J. (1981). Community organization in marine algal epifaunas. A. Rev. Ecol. Syst. 12: 49-74

Sokal, R. R., Rohlf, F. J. (1969). Biometry. Freeman, San Francisco

Soszka, G. J. (1975). Ecological relations between invertebrates and submerged macrophytes in the lake littoral. Ekol. Pol. 23: 393-415

Stoner, A. W. (1980a). The role of seagrass biomass in the organization of benthic macrofaunal assemblages. Bull. mar. Sci. 30: 537-551

Stoner, A. W. (1980b). Perception and choice of substratum by epifaunal amphipods associated with seagrasses. Mar. Ecol. Prog. Ser. 3: 105-111

Stoner, A. W. (1982). The influence of benthic macrophytes on the foraging behavior of pinfish, Lagodon rhomboides (Linnaeus). J. exp. mar. Biol. Ecol. 58: 271-284

Stoner, A. W. (1983). Distributional ecology of amphipods and tanaidaceans associated with three sea grass species. J. Crust. Biol. 3: 505-518

Summerson, H. C., Peterson, C. H. (1984). Role of predation in organizing benthic communities of a temperate-zone seagrass bed. Mar. Ecol. Prog. Ser. 15: 63-77

Sorensen, T. (1948). A method of establishing groups of equal amplitude in plant sociology based on similarity of species content. K. danske Vidensk. Selsk. Skr. (Biol.) 5: 1-35

van Belle, G., Ahmad, I. (1974). Measuring affinity of distribution. In: Proschan, F., Serfling, R. J. (ed.) Reliability and biometry: statistical analysis of lifelength. S.I.A.M., Philadelphia, p. 651-668

Virnstein, R. W., Carbonara, P. A. (1985). Seasonal abundance and distribution of drift algae and seagrasses in the midIndian River lagoon, Florida. Aquat. Bot. 23: 67-82

Virnstein, R. W., Mikkelsen, P. S., Cairns, K. D., Capone, M. A. (1983). Seagrass beds versus sand bottoms: the trophic importance of their associated benthic invertebrates. Fla. Scient. 46: 363-381

Young, D. K., Young, M. W. (1978). Regulation of species densities of seagrass associated macrobenthos: evidence from field experiments in the Indian River estuary, Florida. J. mar. Res. 36: 570-593 